\title{
Model Pembelajaran Cooperative Learning Tipe Reciprokal Teaching Dalam Meningkatkan Hasil Belajar
}

\author{
Nur Rizqi Arifin ${ }^{1}$, Budi Yasri ${ }^{2}$ \\ ${ }^{1}$ Program Studi Pendidikan Akuntansi Fakultas Keguruan dan Ilmu Pendidikan Universitas Galuh \\ Jl. R.E. Martadinata No. 150 Ciamis \\ ${ }^{2}$ Program Studi D3 Metrologi dan Instrumentasi \\ Akademi Metrologi dan Instrumentasi Kementerian Perdagangan \\ Kampus Akmet Jl. Daeng m. Ardiwinata km 3,4 Cihanjuang Bandung Barat 40559 \\ nur.rizqi88@gmail.com ${ }^{1}$ \\ budiyasri@yahoo.com²
}

\begin{abstract}
The low learning outcomes is one of the problems in this study, because learning outcomes are a measure of the success of the learning process. The low learning outcomes are motivated by various factors including the use of learning models by educators. The research method used is an experimental method. Data analysis techniques used were homogeneity test, N-Gain, and t-test. This study produces the following conclusions: 1) There are differences in learning outcomes of students who use the type of cooperative learning model (Reciprocal Teaching) on the initial measurement (Pretest) and final measurement (Postest) with an average pretest value of 49.33 and the average the average posttest score was 83.33. With the N.Gain value of student learning outcomes from pretest to posttest obtained a figure of 0.66. 2) There are differences in learning outcomes of students who use reciprocal teaching cooperative learning models with those using conventional methods at the final measurement (posttest) with the average value of learning outcomes of students who use cooperative learning models of reciprocal teaching type learning in the final measurement (Posttest) of 83.33. While the average value of learning outcomes of students who use conventional learning methods at the final measurement (Posttest) of 62.33 and the results of the $t$ test yielded a tcount of 9.09 with a ttable of 1.67 it can be concluded that $t$ _count> ttable or 9.09> 1.67 (Ha accepted).
\end{abstract}

Keywords: Learning model, Cooperative Learning, Reciprocal Teaching, Learning Outcomes

Abstrak

Rendahnya hasil belajar merupakan salah satu masalah dalam penelitian ini, karena hasil belajar merupakan tolok ukur keberhasilan proses pembelajaran. Rendahnya hasil belajar dilatarbelakangi oleh berbagai faktor diantaranya penggunaan model pembelajaran oleh pendidik. Metode penelitian yang digunakan adalah metode eksperimen. Teknik analisis data yang digunakan adalah uji homogenitas, N-Gain, dan Uji-t. Penelitian ini menghasilkan simpulan sebagai berikut: 1) Terdapat perbedaan hasil belajar peserta didik yang menggunakan model pembelajaran kooperatif tipe (Reciprokal Teaching) pada pengukuran awal (Pretest) dan pengukuran akhir (Postest) dengan rata-rata nilai pretest sebesar 49,33 dan rata-rata nilai posttest sebesar sebesar 83,33. Dengan nilai N.Gain hasil belajar peserta didik dari pretest ke posttest diperoleh angka sebesar 0,66 . 2) Terdapat perbedaan hasil belajar peserta didik yang menggunakan model pembelajaran kooperatif tipe reciprokal teaching dengan yang menggunakan metode konvensional pada pengukuran akhir (posttest) dengan rata-rata nilai hasil belajar peserta didik yang menggunakan model pembelajaran kooperatif learning tipe reciprokal teaching pada pengukuran akhir (Posttest) sebesar 83,33. Sedangkan rata-rata nilai hasil belajar peserta didik yang menggunakan metode pembelajaran konvensional pada pengukuran akhir (Posttest) sebesar 62,33 dan hasil uji t menghasilkan $t_{\text {hitung }}$ sebesar 9,09 dengan $t_{\text {tabel }}$ 1,67 dapat disimpulkan bahwa $t_{\text {hitung }}>t_{\text {tabel }}$ atau 9,09 $>1,67$ (Ha diterima).

Kata kunci: Model pembelajaran, Kooperatif Learning tipe Reciprokal Teaching, Hasil Belajar

\section{PENDAHULUAN}

Rendahnya hasil belajar peserta didik secara tidak langsung kredibilitas seseorang atau peserta didik juga dianggap rendah. Selain itu hasil belajar juga merupakan cerminan dari 
sikap perilaku seseorang atau peserta didik khususnya dari segi pengetahuannya. Orang lain akan beranggapan bahwa seseorang yang memiliki hasil belajar yang kurang baik maka dalam segala hal orang tersebut akan di anggap tidak mampu mengemban tugas yang diberikan.

Hasil belajar adalah sejumlah pengalaman yang diperoleh siswa yang mencakup ranah kognitif, afektif dan psikomotorik. Belajar tidak hanya penguasaan konsep teori mata pelajaran saja, tapi juga penguasaan kebiasaan persepsi, kesenangan, minat-bakat, penyesuaian sosial, macam-macam keterampilan, cita-cita, keinginan dan harapan. (Rusman dalam Suherman, https://ejournal.upi.edu/index.php/JPAK/article/view/15827, diakses tanggal 17 Desember 2019, pukul 22.00 WIB).

Berdasarkan hasil pengamatan yang dilakukan di SMA Negeri 1 Kawali khususnya kelas XI IPS, pada pembelajaran ekonomi peneliti menemukan permasalahn yang cukup menjadi perhatian, yakni rendahnya hasil belajar peserta didik dan proses belajar mengajar di kelas dilakukan dengan metode konvensional (ceramah) dan masih berpusat pada guru. Ketika proses pembelajaran tersebut berlangsung, banyak peserta didik yang kurang memperhatikan, dan ada sebagian peserta didik yang keluar kelas pada saat pembelajaran berlangsung dengan alasan ke kamar mandi. Salah satu karakteristik pembelajaran ekonomi yaitu membutuhkan ingatan untuk mempermudah pemahaman materi (Norani:2012). Selain itu pembelajaran ekonomi juga membutuhkan keaktifan siswa dalam pembelajarannya. Pembelajaran yang pasif akan menghambat kreatifitas pola pikir siswa dalam memahami materi serta dapat menghambat pengembangan materi lebih lanjut. Oleh karena itu perlu adanya kreativitas guru dalam menerapkan metode pembelajaran yang dapat meningkatkan keaktifan siswa untuk mendapatkan hasil pembelajaran yang lebih baik.

Hasil belajar merupakan suatu perubahan tingkah laku dalam diri seorang individu, hasil belajar peserta didik pada dasarnya pengaruh beberapa faktor diantaranya pada internal dan eksternal. Kedua faktor tersebut menyebabkan adanya pengaruh hasil belajar peserta didik yang telah mencapai KKM maupun yang belum mencapai KKM hal tersebut dibutuhkan dengan hasil sebagai peserta didik kelas XI IPS SMA Negeri 1 Kawali . Tahun pelajaran 2018/2019.

Berikut nilai rata-rata UAS mata pelajaran ekonomi kelas XI IPS SMA Negeri 1 Kawali tahun 2018/2019:

Tabel 1. Nilai Ujian Akhir Semester Mata Pelajaran Ekonomi Kelas XI IPS Tahun Pelajaran 2018/2019

\begin{tabular}{ccccccccc}
\hline No & Kelas & KKM & $\begin{array}{c}\text { Nilai } \\
\text { Rata- } \\
\text { rata }\end{array}$ & $\begin{array}{c}\text { Jumlah } \\
\text { Siswa }\end{array}$ & \multicolumn{2}{c}{$\begin{array}{c}\text { Memperoleh Nilai di } \\
\text { Atas KKM }\end{array}$} & \multicolumn{2}{c}{$\begin{array}{c}\text { Memperoleh Nilai di } \\
\text { Bawah KKM }\end{array}$} \\
& & & UAS & & Jumlah & $\%$ & Jumlah & $\%$ \\
\hline 1. & XI IPS1 & 70 & 65,67 & 30 & 11 & 36,67 & 19 & 63,33 \\
\hline 2. & XI IPS2 & 70 & 64,67 & 30 & 9 & 30 & 21 & 70 \\
\hline \multicolumn{3}{c}{ Rata-Rata } & & 20 & 33,34 & & 66,66 \\
\hline
\end{tabular}

Sumber : Guru Mata Pelajaran Ekonomi (2018).

Berdasarkan tabel 1 di atas, diketahui bahwa nilai rata-rata UAS mata pelajaran ekonomi kelas XI IPS SMA Negeri 1 Kawali tahun ajaran 2018/2019 diperoleh nilai ratarata UAS kelas X1 IPS 1 kelas telah mencapai KKM. Kelas XI IPS 1 berjumlah 30 peserta didik dengan angka ketuntasan 11 orang atau 36,67\% sudah di atas KKM dan 19 orang 
atau 63,33\% masih berada di bawah KKM. Sedangkan pada kelas XI IPS 2 berjumlah 30 peserta didik dengan angka ketuntasan 9 orang atau 30\% sudah di atas KKM dan 21 orang atau $70 \%$ masih berada di bawah KKM. Secara umu diketahui bahwa hasil belajar peserta didik di SMA Negeri 1 Kawali masih memiliki masalah.

Rendahnya hasil belajar peserta didik pada mata pelajaran ekonomi dapat disebabkan oleh beberapa faktor. Menurut Suharsimin arikunto (2006:5) "yakni peserta didik itu sendiri,guru,dan personal lainnya, bahkan pelajaran, metode atau teknik dan strategi pembelajaran, sarana penunjang, dan sistem administrasi" Dari faktor-faktor yang mempengaruhi hasil belajar peserta didik salah satunya adalah faktor strategi pembelajaran dimana didalamnya termuat model pembelajaran, model pembelajaran serta teknik pembelajaran yang mempunyai peran dalam meningkatkan hasil belajar peserta didik. Pemilihan teknik pembelajaran yang tepat dapat mempengaruhi hasil belajar peserta didik karena akan memudahkan peserta didik dalam menyerap dan memahami sebuah materi yang dipelajari.

Dengan model pembelajaran yang bervariasi maka peserta didik akan lebih tertarik dan tugas guru dalam menyampaikan materi akan lebih mudah dipahami sehingga tujuan pembelajaran dapat tercapai secara optimal. Kurniasih, Sani (2016:66) mengemukakan bahwa: "Model pembelajaran artikulasi adalah pembelajaran dengan sistem pesan berantai. Metode pembelajaran ini dengan sendirinya akan menuntut siswa aktif karena siswa dibentuk menjadi kelompok kecil yang masing-masing siswa dalam kelompok tersebut mempunyai tugas mewawancarai teman kelompoknya tentang materi yang baru dibahas". Mempelajari ekonomi perlu mengembangkan alternatif variasi model pembelajaran dan latihan-latihan untuk melatih kemampuan dan keterampilan peserta didik. Dalam mempelajari ekonomi, banyak peserta didik SMA Negeri 1 Kawali yang mengalami kesulitan pada materi ekonomi . hasil wawancara dengan guru pengampu mata pelajaran ekonomi pada bulan januari 2019, diketahui bahwa peserta didik memang mengalami kesulitan pada materi perdagangan internasional.

Hasil penelitian Rizky Catur Ananta https://jurnalmahasiswa.unesa.ac.id/index.php/jmtp/article/view/12429 diakses tanggal 17 desember 2019, pukul 10.43 WIB bahwa; model pembelajaran kooperatif tipe Reciprocal Teaching dapat meningkatkan hasil belajar siswa secara signifikan dibandingkan dengan menggunakan model pembelajaran konvensional pada proses pembelajaran Geografi materi Hubungan Manusia dan Lingkungan Akibat Dinamika Hidrosfer siswa kelas X di SMAN 1 Krembung Sidoarjo. Dalam proses pembelajaran dengan menggunakan model pembelajaran berbalik (Reciprocal Teaching) siswa lebih aktif berdiskusi dan menemukan berbagai cara dalam memecahkan masalah. Vahlia, Sudarman (2015). http://ojs.fkip.ummetro.ac.id/index.php/matematika/article/view/94, diakses tanggal 17 desember 2019, pukul 10.43 WIB.

Melihat dari masalah yang di temukan di lapangan maka diperlukan suatu cara untuk meningkatkan hasil belajar peserta didik di SMA Negeri 1 Kawali dengan mengubah proses pembelajaran. Langkah yang harus dilakukan guru dalam proses pembelajaran, guru dituntut menerapkan model pembelajaran yang inovatif tipe pembelajaran Reciprokal Teaching Model ini adalah salah satu tipe yang dapat berpengaruh terhadap hasil belajar peserta didik yang dapat digunakan sebagai alternatif untuk meningkatkan keaktifan dan kemandirian peserta didik.

Salah satu cara untuk meningkatkan hasil belajar peserta didik diantaranya dengan menggunakan salah satu model pembelajaran Reciprokal Teaching model pembelajaran 
yang memberikan kesempatan kepada peserta didik pada kesempatan untuk mempelajari materi terlebih dahulu, kemudian peserta didik menjelaskan kembali materi yang dipelajari kepada peserta didik yang lain. Guru hanya bertugas sebagai fasilitator dan pembimbing dalam pembelajarannya, yaitu meluruskan atau memberi penjelasan mengenai materi yang tidak dapat dipecahkan secara mandiri oleh peserta didik.

\section{METODE PENELITIAN}

Metode yang digunakan dalam penelitian ini yaitu metode eksperimen. Metode yang digunakan dalam penelitian ini adalah metode eksperimen. Menurut Sugiyono (2016:11) bahwa; "Penelitian eksperimen merupakan metode penelitian yang digunakan untuk mencari pengaruh treatment (perlakuan) tertentu". Dalam penelitian eksperimen, terdapat beberapa bentuk desain antara lain pre-eksperimental design, nonequivalent contol group design, true eksperimental design, factorial design, dan quasi eksperimental design. Adapun desain yang dipilih oleh peneliti adalah nonequivalent contol group design. Sedangkan metode yang digunakan dalam penelitian ini yaitu metode eksperimen dengan desain Nonequivalent Contol Group Design. Menurut Sugiyono (2017: 79), bahwa:

Dalam penelitian ini akan terdapat dua kelompok yang tidak dipilih secara random. Keduanya kemudian diberi prates untuk mengetahui keadaan awal dan perbedaan antara kelompok eksperimen dan kelompok kontrol. Hasil prates yang baik adalah bila nilai kelompok eksperimen dalam kelompok kontrol tidak berbeda secara signifikan.

\section{HASIL DAN PEMBAHASAN}

a. Hasil Belajar Peserta Didik yang Menggunakan Model Pembelajaran Kooperatif Learning Tipe Reciprokal Teaching pada Pengukuran Awal (Pretest) dan Pengukuran Akhir (Posttest)

Perbedaan hasil belajar peserta didik yang menggunakan Model Pembelajaran Kooperatif Learning Tipe Reciprokal Teaching pada pengukuran awal (pretest) diperoleh nilai rata-rata sebesar 49,33 dan hasil pengukuran akhir (posttest) diperoleh nilai rata-rata sebesar 83,33. Dengan demikian hasil belajar peserta didik dari pretest ke posttest di kelas eksperimen terdapat perbedaan sebesar 34. Perbedaan ini bila di presentasikan mengalami peningkatan sebesar 40,8\%. N.Gain hasil belajar peserta didik dari pretest ke posttest diperoleh angka sebesar 0,66 .

Sedangkan hasil perhitungan uji t diketahui bahwa nilai $t_{\text {hitung }}$ sebesar 7,6196 sedangkan nilai $t_{\text {tabel }}$ berdasarkan hasil perhitungan dengan rumus interpolasi di atas diperoleh nilai $\mathrm{t}_{\text {tabel }}$ dengan derajat kebebasan 58 pada taraf kepercayaan 95\% atau taraf signifikansi 0,05 sebesar 1,67. Berdasarkan perhitungan tersebut diketahui bahwa nilai $t_{\text {hitung }}>$ nilai $t_{\text {tabel }}$ atau $7,6196>1,67$, hal ini berarti terdapat perbedaan hasil belajar peserta didik yang menggunakan model pembelajaran kooperatif learning tipe reciprokal teaching pada pengukuran awal (pretest) dan pengukuran akhir (posttest).

Hasil analisis tersebut sejalan dengan pendapat Jumanta Handayana (2017:201), yang menjelaskan bahwa; Pembelajaran Reciprokal Teaching: dapat meningkatkan kemampuan siswa dalam dalam berdiskusi antara guru dan siswa maupun siswa dan siswa yang memberikan kesempatan berfikir dan saling bertukar pengalaman belajar yang berdasarkan 
prinsip-prisip pengajuan pertanyaan melalui pelajaran langsung dan permodelan yang diberikan oleh guru di kelas.

b. Perbedaan Hasil belajar Peserta Didik yang Menggunakan Model Pembelajaran

Kooperatif Learning Tipe Reciprokal Teaching dengan yang Menggunakan Metode

Pembelajaran Konvensional pada Pengukuran Akhir (Posttest)

Perbedaan hasil belajar peserta didik yang menggunakan model pembelajaran kooperatif learning tipe reciprokal teaching pada pengukuran akhir (Posttest) memiliki nilai rata-rata lebih tinggi dibandingkan dengan yang menggunakan metode pembelajaran konvensional. Rata-rata nilai hasil belajar peserta didik yang menggunakan model pembelajaran kooperatif learning tipe reciprokal teaching pada pengukuran akhir (Posttest) yaitu sebesar 83,33. Sedangkan rata-rata nilai hasil belajar peserta didik yang menggunakan metode pembelajaran konvensional pada pengukuran akhir (Posttest) yaitu sebesar 62,33.

Sedangkan hasil perhitungan uji t diketahui bahwa nilai $t_{\text {hitung }}$ sebesar 9,09 sedangkan nilai $t_{\text {tabel }}$ berdasarkan hasil perhitungan dengan rumus interpolasi di atas diperoleh nilai $t_{\text {tabel }}$ dengan derajat kebebasan 58 pada taraf kepercayaan 95\% atau taraf signifikansi 0,05 sebesar 1,67. Berdasarkan perhitungan tersebut diketahui bahwa nilai $t_{\text {hitung }}>$ nilai $t_{\text {tabel }}$ atau $9,09>1,67$, hal ini berarti terdapat perbedaan hasil belajar peserta didik yang menggunakan model pembelajaran kooperatif learning tipe reciprokal teaching dibandingkan dengan yang menggunakan metode pembelajaran konvensional pada pengukuran akhir (posttest).

Dengan demikian hasil belajar peserta didik pada pengukuran akhir di kelas eksperimen lebih unggul dibandingkan dengan hasil belajar peserta didik di kelas kontrol. Artinya penerapan model pembelajaran kooperatif learning tipe reciprokal teaching berpengaruh terhadap hasil belajar peserta didik pada mata pelajaran ekonomi pada kompetensi dasar menganalisis pertumbuhan ekonomi dan pembangunan ekonomi di kelas XI IPS SMA Negeri 1 Kawali .

\section{KESIMPULAN}

Bertitik tolak dari tujuan penelitian, yaitu ingin mengetahui pengaruh penerapan penerapan model pembelajaran kooperatif learning tipe reciprokal teaching terhadap hasil belajar peserta didik pada mata pelajaran ekonomi, berdasarkan hasil pengolahan data dan analisis data yang dilakukan melalui pengujian hipotesis dapat disimpulkan bahwa terdapat perbedaan hasil belajar peserta didik yang menggunakan model pembelajaran kooperatif tipe (Reciprokal Teaching) pada pengukuran awal (Pretest) dan pengukuran akhir (Postest) dengan rata-rata nilai pretest sebesar 49,33 dan rata-rata nilai posttest sebesar sebesar 83,33. Dengan nilai N.Gain hasil belajar peserta didik dari pretest ke posttest diperoleh angka sebesar 0,66. Selanjutnya terdapat perbedaan hasil belajar peserta didik yang menggunakan model pembelajaran kooperatif tipe reciprokal teaching dengan yang menggunakan metode konvensional pada pengukuran akhir (posttest) dengan rata-rata nilai hasil belajar peserta didik yang menggunakan model pembelajaran kooperatif learning tipe reciprokal teaching pada pengukuran akhir (Posttest) sebesar 83,33. Sedangkan rata-rata nilai hasil belajar peserta didik yang menggunakan metode pembelajaran konvensional pada pengukuran akhir (Posttest) sebesar 62,33 dan hasil uji t menghasilkan $t_{\text {hitung }}$ sebesar 9,09 dengan $t_{\text {tabel }} 1,67$ dapat disimpulkan bahwa $t_{\text {hitung }}>t_{\text {tabel }}$ atau 9,09 $>1,67$ (Ha diterima). 


\section{DAFTAR PUSTAKA}

[1] Arikunto, S. (2006). Prosedur Penelitian Suatu Pendekatan Praktik. Jakarta: Rineka Cipta.

[2] Hamdayana, Jumanta. (2014). Model dan Metode Pembelajaran Kreatif dan Berkarakter. Bogor: Ghalia Indonesia

[3] Kurniasih, Imas\&Berlin Sani. 2016. Ragam Pengembangan Model Pembelajaran Untuk Meningkatkan Profesionalitas Guru. Jakarta: Kata Pena.

[4] Rusman dalam Suherman, Ade. 2018. https: //ejournal.upi.edu/index.php/JPAK/article/view/15827, diakses tanggal 17 Desember 2019, pukul 22.00 WIB).

[5] Ananta, Catur, R. (2015). Penerapan Model Pembelajaran Kooperatif Tipe Reciprocal Teaching Untuk Meningkatkan Hasil Belajar Mata Pelajaran Geografi Materi Hubungan Manusia Dan Lingkungan Akibat Dinamika Hidrosfer Siswa Kelas X Di Sman 1 Krembung Sidoarjo. https://jurnalmahasiswa.unesa.ac.id/index.php/jmtp/article/view/12429 diakses tanggal 1 desember 2019, pukul 10.43 WIB bahwa.

[6] Vahlia, Sudarman,(2015).Penerapan Model Pembelajaran Berbalik (Reciprocal Teaching) Ditinjau Dari Aktivitas Dan Hasil Belajar Siswa http://ojs.fkip.ummetro.ac.id/index.php/matematika/article/view/94, diakses tanggal 17 desember 2019, pukul 10.43 WIB. 